\title{
Beyond the Glamour: Resident Perceptions of Olympic Legacies and Volunteering Intentions
}

\begin{abstract}
This study examines factors that influence residents' volunteering behaviours postcompletion of the London 2012 Olympic and Paralympic Games. It posits that residents' interactions with the event over time and their perceptions of event legacies are likely to exert influence on volunteering. Data were collected in two phases between January 2013 and April 2016 amongst residents living in the borough of Weymouth and Portland. The borough is in the county of Dorset in the South West of England, and was the host destination for the sailing events of the 2012 Games. Our findings revealed that residents' intention to volunteer post-Games declined from 2013 and 2016. Actual volunteering experience, perceived event legacy, commitment to the community, age and length of residence were found to contribute significantly to future volunteering intentions. While the results provide insights for those seeking to develop event legacy strategies to both recruit volunteers and to better leverage volunteering opportunities, it also cautions the claim of positive volunteering legacy made by the 2012 Games.
\end{abstract}

Keywords: Volunteering, Olympic Games, residents, perceptions, legacy, time 


\section{Introduction}

Volunteers are heralded as an essential component of the Olympic and Paralympic Games and a key contributor towards the delivery of a successful event (Lockstone-Binney, Holmes, Shipway, \& Smith, 2016). Volunteering programmes for mega-events such as the Olympic Games provide an opportunity for locals to become involved and are often oversubscribed due to the 'prestige' or 'glamour' factors (Lockstone \& Baum, 2009). However, questions remain about the extent to which the Olympic Games have the ability to deliver ongoing volunteering legacy within host communities once the novelty and glamour have passed (Shipway, 2007). As Doherty (2009) highlighted, there is limited knowledge about the volunteer legacies that may result from volunteering at mega-events. Given legacy inclusion plays a vital role in an Olympic bid (Bell \& Gallimore, 2015), an understanding of residents' perceptions and attitudes toward volunteering can inform legacy planning and mega-event leveraging strategies.

While there is a significant body of literature on mega-event legacies in general (Davies, 2012; Leopkey \& Parent, 2017), there is a relative paucity of studies that focus on the post-event development of volunteering within host communities over an extended period of time. This is mainly due to the challenge of assessing volunteers' behaviours after the mega-event as the organising committees often have sunset clauses that limit access to volunteer databases (Dickson, Darcy, Edwards, \& Terwiel, 2015). As such, much of the research exploring volunteering legacies only measures pre-event or in-event behaviours as a surrogate to ascertain future volunteering intentions (Dickson et al., 2015) or to "provide a sense of the volunteer legacy of [the] Games' (Love, Hardin, Koo, \& Morse, 2011, p. 200). While a handful of studies have attempted to address this issue by surveying volunteering sometime after the event (e.g., Dickson et al., 2015; Hallmann \& Harms, 2012), they were not conducted over a long period of time to demonstrate a legacy. This limitation is highlighted 
by Dickson, Benson, and Blackman (2011), who suggested that existing legacy literature often lacks 'substantive empirical research in respect of pre, during and, in particular, postevent research' (p. 292).

Some researchers proposed that the legacy of volunteering is not limited to those who actually volunteer at the event itself (Fairley, Cardillo, \& Filo, 2016a). Given the sustainability of mega-events requires substantial community support (Gursoy \& Kendall, 2006), residents' inputs and perceptions of legacies are crucial (Karadakis \& Kaplanidou, 2012). This paper aims to fill a research gap by examining the factors, in particular perceptions of the Olympic legacies, that influence volunteering behaviour from the resident's perspective, focusing specifically on the London 2012 Games. Shipway (2007) further argued that an extended post-event study is important, given that the 2012 Games provided detailed legacy plans as part of their bid documentation that have implications for communities and social inclusion agendas within host cities and host destinations.

With this in mind, the present study extends temporal evaluations of volunteering legacies by examining residents' perceptions of legacies associated with the London 2012 Olympic Games and how these alter in the years after the event. As certain outcomes including volunteer programme objectives take time to evolve and deliver tangible outcomes, it is reasonable to assess these event impacts and volunteering legacies over a period of time, especially after the Games have concluded. The study draws on data collected post-event at two different time intervals in 2013 and 2016 respectively. Intention to volunteer is examined along with perceived legacies, to better understand residents' opinions towards volunteering at the 2012 Games, and to assist with more effective planning on how mega-events can be strategically leveraged amongst host communities to create long-lasting benefits. 


\section{Literature Review}

\section{Mega event impacts and legacies}

One of the justifications to local communities for hosting mega-events is linked to the longterm benefits that remain once the event has concluded (Dickson et al., 2011). The increasingly important role of legacy planning at the Olympic and Paralympic Games has been recognised by researchers (Davies, 2012; Fairley, Gardiner, \& Filo, 2016b; Leopkey \& Parent, 2012; Lockstone-Binney et al., 2016) and is illustrated through the inclusion of specific focus within the Olympic charter of the International Olympic Committee (IOC). The terms 'impacts' and 'legacies' are often used interchangeably, although legacy incorporates a broader range of impacts that can be sustained after the event (Kaplanidou et al., 2013). The precise concept of 'legacy' remains ambiguous and highly contested due to its undetermined duration (Pappalepore \& Duignan, 2016). Several researchers have also cautioned about defining legacy as a solely positive concept (Dickson, Benson, \& Blackman, 2011; Leopkey \& Parent, 2017; Shipway, 2007).

Given the diverse range of consequences that can result from hosting a mega-event, differing interpretations and meanings of legacy have emerged. According to Preuss (2007, p. 211), 'irrespective of the time of production and space, legacy is all planned and unplanned, positive and negative, tangible and intangible structures created for and by a sport event that remain longer than the event itself'. This definition is appropriate for this study as it examines changes in resident perceptions of event impacts and volunteering over time, and the postevent perspectives on volunteering that remain after the Games. The IOC further recognised that 'delivering legacy requires strong partnerships between city leaders, the Games organisers, regional and national authorities and local communities' (IOC, 2012, p. 58).

Planning for sustainable Olympic legacies should take place before the event (Shipway, 2007). This includes the impact of volunteering programmes and their impact upon 
local residents, as according to the IOC (2012), 'positive legacy does not simply happen by itself. It needs to be planned and embedded in the host city's vision from the earliest possible stage' (p.58). However, the lack of post-Games legacy organisations indicates that stakeholder engagement, including with host communities, does not always occur (Benson, Dickson, Terwiel, \& Blackman., 2014; Dickson et al., 2011; Minneart, 2012). Questions also remain about how long legacies last, where they should occur, and at what costs (Duignan, Pappalepore, \& Everett, 2019; Smith, 2014).

With the aim of developing clarity surrounding the concept of Olympic legacy, in 2014 the IOC initiated Olympic Agenda 2020 to provide strategic direction for organising the Olympic Games, including a variety of legacy specific recommendations (IOC, 2014). Within the initial Olympic Agenda 2020 proposals, engaging with communities and the role of volunteers were briefly mentioned in recommendation 23 of 40 proposed recommendations, that were later refined to focus on six key aspects of organising the Olympic Games. To address those six areas, the IOC established three major initiatives from candidature to delivery and legacy in a report by the Executive Steering Committee for Olympic Games Delivery, commonly referred to as Olympic Agenda 2020: the New Norm (IOC, 2018), including a series of policies to assess and develop Games legacies. In the report, the IOC conceptualised Olympic legacy, summarising that 'It encompasses all the tangible and intangible long-term benefits initiated or accelerated by the hosting of the Olympic Games / sports events for people, cities / territories and the Olympic Movement' (IOC, 2018, p. 5). The aim of the New Norm report was to formally embed legacy planning into every stage of Olympic preparations. 


\section{Resident perceptions of legacies}

Whilst many legacy studies have traditionally focused on the economic impacts, there has been a growing recognition for a more holistic approach to event planning and evaluation (Fredline, Raybould, Jago, \& Deery, 2005). Ritchie (2000) argued that the underlying idea of legacy is that it represents something of substance that will enhance the long-term well-being or lifestyle of residents in a significant manner, preferably in a way that reflects the values of the local community. He stressed that planning for positive and sustainable legacies should involve all stakeholders who will be affected by and benefit from these outcomes (Ritchie, 2000). Similarly, Gold and Gold (2008) noted that one of the justifications for hosting megaevents are the intergenerational benefits they generate, which allegedly will repay the costs borne by the community to benefit future generations.

As residents are an important stakeholder of mega-events, the planning and measurement of legacies should be understood from their perspective (Karadakis \& Kaplanidou, 2012). Residents' involvement helps generate a festive atmosphere and provide positive experience for visitors (Prayag, Hosany, Nunkoo, \& Alders, 2013); hence, the sustainability of mega-events relies on the extent to which the community's views are taken into consideration in the planning process (Gursoy \& Kendall, 2006; Zhou \& Ap, 2009). In addition, residents are likely to have more positive attitudes toward the event if they perceive hosting the event will bring individual benefits that might outweigh costs (Ritchie, Shipway, \& Cleeve, 2009). However, as residents often face the dilemma of balancing a trade-off between making individual sacrifices in the short term and the possible collective community benefits in the longer term (Chien, Ritchie, Shipway, \& Henderson, 2012; Smith, Ritchie, \& Chien, 2019), measurement of the social impacts of mega-events can be particularly challenging as they remain difficult to establish or quantify (Ritchie et al., 2009). 
To date, social legacies that include volunteering have received far less attention in comparison with measurable, more tangible legacy programmes such as infrastructure development, and as such long-term post-event legacy studies have been limited (Dickson et al., 2011; Nichols, 2013; Lockstone-Binney et al., 2016). Scholars have suggested that megaevent hosting decisions should be justified in terms of non-infrastructural, intangible, or 'soft' legacies, where social impact assessment such as feelings of pride amongst residents and community benefits such as increase in post-event volunteering represents an important measure (Gibson et al., 2014; Liu et al., 2014; Kaplanidou et al., 2013; Minnaert, 2012).

In the context of the Rio 2016 Olympic Games, Rocha, Barbant and Chelladurai (2017) found that residents supported the Games based on reciprocity and community gains, but they were somewhat sceptical on positive legacies for Brazil and as such were only moderately supportive of the 2016 Games. As the impact of events is dynamic and may continue to evolve, residents' opinions and assessment of event impacts may change over time (Kaplanidou et al., 2013; Kim \& Petrick, 2005) and it is yet to be determined at this stage the perceptions of legacy among Rio residents. It follows that research examining mega-event legacies should not be restricted to studies that take place during the bidding or hosting stages, and should adopt a longer-term approach to examine post-event variations at several time intervals (Holmes et al., 2015; Lockstone-Binney et al., 2016).

\section{Mega-event legacies and volunteering}

Volunteers and the broader voluntary sector are increasingly recognised as an important stakeholder involved in the delivery of mega-events (Fairley, Kellett, \& Green, 2007; Shipway, Lockstone-Binney, Holmes, \& Smith, 2019). It is acknowledged that volunteers make a significant contribution to the success and effectiveness of mega-events and their interaction with other event stakeholders has become an area of greater scrutiny (Holmes, 
Lockstone-Binney, Smith, \& Shipway, 2018; Nichols, 2013; Nichols \& Ralston, 2015;

Nichols, Ralston, \& Holmes, 2017). Retaining volunteers from year to year is a challenge for organisers at many major events (Fairley et al., 2007). Keeping repeat volunteers, however, can have added benefits as these volunteers bring with them skills and knowledge that were obtained through previous experiences. Prior research on volunteering legacies often seek to understand volunteering motives (Fairley et al., 2007) and examine programmes that might encourage repeat volunteering at the same event (Elstad, 2003) or in the event host city as part of a community or social legacy (Doherty, 2009).

Residents provide an important pool of volunteers, with a great potential of repeat volunteering (Chien, Kelly, \& Gill, 2018). Although the majority of volunteering research has focused on residents of the host city, an increasing number of studies have shifted their attention to non-host communities. For example, Fairley et al. (2016a) explored regional residents' perceptions of the 2018 Commonwealth Games, and found that non-host community residents were unaware of the volunteering opportunities and demonstrated a reluctance to volunteer for various reasons. While the study had a focus on non-host communities, it did illustrate the need to better communicate and engage with residents in activities over time which might also lead to opportunities to better leverage volunteering opportunities from the event.

Holmes and Smith (2009) indicated that, in contrast to the plethora of studies that assess volunteer motivations, there has been little attention given to individual volunteering in host cities/destinations, and how this might be developed as a legacy of mega-events like the Olympic Games. This point was supported by Wicker (2017) in her reflection on existing research on volunteerism and volunteer management in sport. Outside of the Olympic context, Nichols and Ralston (2012) identified the importance of creating longer term benefits for host cities and local residents as a positive legacy, and highlighted the 
Manchester 2002 Commonwealth Games' development of a pool of specialist local event volunteers as an effective mechanism to assist with fostering repeat volunteering.

As highlighted by some researchers (e.g., Auld, Cuskelly, \& Harrington, 2009; Chien et al., 2018; Fairley et al., 2016b), the volunteering legacy of a mega-event is not only restricted to an impact on volunteering at sport or events, it may have an impact on the broader community. Given the number of volunteers and the collected involvement and euphoria, there is considerable potential for developing legacies of continued volunteering (Nichols et al., 2017). However, researchers have raised concerns and reservations about the role of government structures and political interference and the subsequent impact these may have on effective delivery of volunteering legacies at the Olympic Games (Bell \& Gallimore, 2015; Nichols \& Ralston, 2015; Shipway et al., 2019). Despite these studies, there still remains a relative paucity of academic exploration of these softer legacies, particularly those involving volunteering (Doherty, 2009: Nichols et al., 2017), and in respect to evaluating residents' future volunteering intentions in a post-event legacy era, this study begins to fill this research gap.

Both Shipway (2007) and Leopkey and Parent (2012) suggested that the measuring of legacies is complex as they are multifaceted and dependent on a variety of local and global factors. Hiller and Wanner (2011) indicated that as event outcomes take time to develop and residents' interactions with the event will change over time, then their perceptions of legacies are also likely to vary. In the context of the 2010 FIFA World Cup, Kaplanidou et al. (2013) measured host city residents' perceptions of event impacts so as to ascertain their overall satisfaction of quality of life and support for the event. In other words, perceived event legacies may influence residents' evaluations of life outlook and behaviour. With regards to the temporal dimensions of legacy evaluation, consideration should be given to the time that legacy occurs beyond the event (Dickson et al., 2011; Lockstone-Binney et al., 2018; 
Shipway et al., 2019), in order to determine the level and impact of the legacy upon the community and their broader perceptions and attitudes towards volunteering at sports events. As such, an approach to monitor mega-event legacies over a prolonged period of time could be particularly insightful.

Following previous studies (e.g., Karadakis \& Kaplanidou, 2012; Kaplanidou et al., 2013), this paper seeks to advance research knowledge by examining residents' volunteering behaviours post-event. Specifically, the research objectives are: (1) to understand if residents' perceived mega-event legacies influence their support for volunteering over an extended period of time, and (2) to identify factors that may influence residents' volunteering behaviours. Fundamentally, this study extends understanding of Olympic legacy by examining the long-term attitudes amongst host communities towards volunteering as a result of hosting the London 2012 Games.

\section{Methods}

\section{Research setting}

The present study - as part of a broader ongoing resident project for the London 2012 Olympic and Paralympic Games - aims to examine residents' perceptions of event legacies, as well as their support for volunteering and future volunteering intentions. It was conducted in the borough of Weymouth and Portland, located in the county of Dorset, England. The borough hosted the sailing events of the 2012 Games, and according to the 2011 UK population census has a population of 65,167 residents (Nomis, 2017). The Games provided residents opportunities for involvement with the sailing events, including volunteering opportunities (Shipway, Henderson, \& Stuchberry, 2010), and various legacy strategies at local, regional and national levels incorporating plans for enhanced volunteering opportunities. 
The Olympic Games is the largest recurring global sports event using volunteers (Nichols et al., 2017) and the London 2012 Games deployed 70,000 official volunteers known as "Games Makers", providing support roles at event venues (Lockstone-Binney et al., 2018). There were also several other volunteer programmes established during the Games, in London and at other regional locations that hosted Olympic events (Nichols \& Ralston, 2014). This included Weymouth and Portland National Sailing Academy with the provision of logistical support at the Olympic venue, tourist information centre, railway station and other public venues within the host borough.

The data presented here were collected via a survey during two post-Games periods. The first collection took place approximately four months after the finish of the event in January 2013, with the second study conducted during April 2016, approximately 3.5 years after the completion of the Games. This study seeks to monitor changes in residents' perceptions of event legacies and their impact on volunteering. It also aims to establish linkages between these perceptions within the communities of Weymouth and Portland and the broader national, regional and local legacy objectives for the 2012 Games, and in doing so better understand residents' level of support for volunteering at future major events.

\section{Independent variables}

This study measured several event legacies to determine if residents' perceptions vary across legacy types. A total of 14 perceived legacy items relating to sporting, economic, and community impacts were included in the 2013 and 2016 studies. The items were adapted from the literature (Dickson et al., 2011; Preuss, 2007; Shipway, 2007), as well as from documents published by government departments responsible for the Olympic legacy planning at a national, regional and local level (DCMS, 2016; SWRDA, 2007). Sample items included "The 2012 Games brought new facilites that the borough will benefit from and be 
able to use" (sporting legacy), "The 2012 Games has provided opportunities for businesses after the event" (economic legacy), and "The 2012 Games brought the community together" (social legacy). Residents were asked to indicate on a 5-point Likert scale ( $1=$ extremely unlikely to $5=$ extremely likely) how likely that these potential legacies have or will be met at a national, regional and local level. The items were combined to create a composite score. Across the 2013 and 2016 data, Cronbach's alpha reliability coefficients were estimated at .95 for all perceived legacy items.

Residents were also instructed to complete questions related to their event attendance, involvement in sailing and tourism employment. Responses to these questions were measured using a dichotomous scale (i.e., yes or no). These factors have been found to influence event support and perceived legacies in past studies (Cegielski \& Mules, 2002; Ritchie et al., 2009). Residents also provided information about their socio-demographics such as gender, age, length of residence in the Borough, and residence's distance to the event venues, all of which could potentially influence residents' views towards both the hosting of the Games and more specifically towards volunteering (Chien et al., 2012). Commitment to the 2012 Olympics overall and the destination were also measured as covariates as they have been found to be important factor in past studies (Chien at al., 2012).

\section{Dependent variables}

Two key behavioural outcome variables were measured in this study. Residents were asked to indicate their actual event volunteering during the 2012 Olympics Options in a dichotomous scale (i.e., yes or no). Residents' intention to volunteer for future events was also measured by a dichotomous scale. Skewness and normality assumptions were upheld after 35 outliers were removed from the data file. Regression analyses were undertaken to understand whether the independent variables were associated with the dependant variables. 


\section{Sampling and procedures}

A self-completion questionnaire was used to examine residents' response to the hosting of the Olympic sailing events, consisting of four pages and two sections. The first section requested answers to questions on the independent and dependent variables. Many of the statements were adapted from previous event impact studies (e.g., Fredline \& Faulkner, 2002; Kim, Gursoy, \& Lee, 2006; Ritchie \& Inkari, 2006). The second section compiled data on resident demographics.

There was a slight variation in the administering procedures used in 2013 data collection and that used in the 2016. In the first phase, the "drop and collect" method (also known as drop-off delivery or self-completion) was used, involving the hand delivery and recovery of the questionnaires. This technique was deemed reliable and cost effective and involved elements of personal contact which has been demonstrated to improve the response rates (Chien et al., 2012). In 2016, due to time and resource constraints a standardised postal survey was used. Despite these differences, the surveys in both 2013 and 2016 were equally distributed across the 15 wards of the borough of Weymouth and Portland, using a systematic sampling procedure and street ward index whereby streets were randomly selected after numbering (Ritchie et al., 2009; Ritchie, Shipway, \& Chien, 2010). In both phases residents received a cover letter that explained the purpose of the study with the questionnaire. The questionnaire took approximately ten minutes to complete and respondents had the opportunity to win a $£ 50$ store voucher.

Table 1 provides a breakdown of the total number of questionnaires distributed, the number of usable returned questionnaires, and the response rate. In the first phase where the “drop and collect" method was adopted, an attempt to collect was made 48 hours after distribution, and where residents were not present, pre-paid envelopes were provided so the 
questionnaire could be returned by post. In 2016, as a standardised postal survey was used, respondents were provided with a pre-paid envelope to return the completed questionnaire. Insert Table 1 about here

Notably, the response rate in 2016 was lower than the 2013 survey. This was anticipated as the decrease in response rate was possibly due to the combination of resident fatigue with 'Olympic' questionnaires, a 3.5-year time lapse since the end of the 2012 Games, and also the use of a postal survey rather than the more personable approach of the "drop and collect" method used in the first phase. The response rate, however, remained consistent with other similar resident opinion studies (Gursoy, Yolai, Ribeiro, \& Panosso Netto, 2017; Zhou \& Ap, 2009).

\section{Results}

\section{Descriptive statistics}

A total of 1,494 responses were recorded across 2013 and 2016, with 929 responses recorded in 2013 and 565 responses in 2016. The demographic profile was largely representative of the local population based on a comparison to census data (Office for National Statistics, 2017), although a Chi-square test showed a statistical difference $\left(\chi^{2}=18.713, p<0.01\right)$ with fewer females completing the study in 2016 (44\%) compared with 2013 (53\%). Age ranges were from 16 to 65 years and above, with the majority of respondents being older than 46 years in both 2013 and 2016 samples (60.9\% and 70.6\%) compared with 50\% from the census figures (Office for National Statistics, 2017). A Chi-square test showed significant differences between age distribution of the two samples $\left(\chi^{2}=25.330, p<0.01\right)$ with the 2016 sample having a higher percentage of those aged over 65 years compared to the 2013 sample. Approximately $80 \%$ of the respondents had been a local resident for 11 or more years, while $40 \%$ lived four or more miles from the event venues. A total of $6 \%$ of respondents were 
employed in the tourism sector and $19 \%$ were involved in sailing or water sports. No statistical differences were found between samples based on these characteristics. Previous studies have reported variations in age and gender (see Lee et al., 2012), as well as differences between income and education across pre- and post-event samples (Kaplanidou et al., 2013).

\section{Volunteering experience}

A total of $4.7 \%$ of respondents in 2013 indicated they had volunteered at the 2012 Olympic Games in Weymouth and Portland, compared to 3.8\% of respondents in 2016. There were no differences in reported volunteering at the 2012 Olympic Games between the 2013 and 2016 samples $(p=0.431)$ indicating consistency across the time periods, even with a cross sectional study. A total of $24.3 \%$ of the sample in 2013 indicated they would volunteer for future events in Weymouth and Portland but this dropped in 2016 to $6.5 \%$ of the sample $\left(\chi^{2}=\right.$ $72.244, p<0.01)$

\section{Explaining volunteering}

A binary logistic regression was performed to assess the influence of the independent variables on residents' volunteering at the 2012 Olympic events and their intentions to volunteer at future events. The purpose of this analysis was to understand factors that influence volunteering in the past and future. A logistical regression was chosen because the dependant variables were dichotomous. A range of covariates was also entered into the regression model as control variables, including socio-demographics (age, gender, location, length of residence, location), as well as event attendance, commitment to the community, involvement in sailing, and employment in the tourism industry. Categorical variables were transformed into dummy variables. Reported 2012 event volunteering was added as variable 
for understanding future event volunteering, as studies suggest that volunteering at megaevents can encourage future volunteering (Dickson, Benson, Blackman, \& Terwiel, 2013; Dickson, Benson, \& Terwiel, 2014).

For the models examining associations with residents' actual event volunteering, the model containing all the variables was statistically significant $\left(\chi^{2}=61.057, p<0.001\right)$ for the 2013 sample. The model as a whole explained between 8.0\% (Cox and Snell $\mathrm{R}^{2}$ ) and $24.7 \%$ (Nagelkerke $\mathrm{R}^{2}$ ) of the variance in event volunteering and correctly classified $95.1 \%$ of cases. The results showed that two independent variables made a statistically significant contribution to the model. The strongest variable was involvement in water sports with an odds ratio of $.182(\beta=-1.702, p<.001)$, followed by location of residence with an odds ratio of $.395(\beta=-.929, p=.035)$. This means that those involved in sailing or water sports activities and living 4+ miles away from the event venues were significantly less likely to have participated as event volunteers. Yet in the case of those involved in sailing and water sports they were perhaps more appropriate volunteers considering that Weymouth and Portland was the site of the sailing events. Put another way, those not involved in sailing or water sports and those located within 4 miles from the venues were a lot more likely to have volunteered. It also implied that both interest and involvement in volunteering was more widespread than those solely with sailing interests, suggesting a broader appeal (Shipway, Henderson, \& Stuchberry, 2010). There were no statistically significant predictors in the 2016 model $\left(\chi^{2}=21.484, p=.122\right)$ including perceived legacies.

For the models examining associations with future volunteering intentions, the model containing all the variables was statistically significant for the 2013 sample, $\chi^{2}(21, \mathrm{~N}=546)$ $=76.020, p<.001$. The model as a whole explained between $25.2 \%\left(\right.$ Cox and Snell $\left.\mathrm{R}^{2}\right)$ and $35.3 \%$ (Nagelkerke $\mathrm{R}^{2}$ ) of the variance in future volunteering intentions, and correctly classified $77.7 \%$ of cases. As shown in Table 2, five independent variables made a unique 
statistically significant contribution to the model. The strongest predictor of future volunteer intention was actual volunteering, recording an odds ratio of 12.3 . The second strongest positive association was age, with those aged between 36-45 years recording an odds ratio of 4.07 and 46-55 years with an odd ratio of 3.35. Age was followed by those who have lived in the area for between 1-3 years with an odds ratio of 4.5. For each unit increase in perceived legacies and commitment to the community, the odds of future volunteering also increased (see Table 2). The odds ratio of 0.87 for tourism involvement (considered themselves employed in the tourism industry) was less than one, indicating that for every additional tourism involvement respondents were 0.87 times less likely to report future volunteer intention, controlling for other factors in the model. These findings suggested that those involved in volunteering would continue to volunteer for future events, as a contrast to those involved in tourism, who were less likely to commit to volunteering in the future.

\section{Insert Table 2 about here}

For the 2016 sample the full model was not statistically significant $\left(\chi^{2}=28.027 p=\right.$ .134). Although the overall model was not significant, the classification table showed that the individual item measuring volunteering at the 2012 Olympics in Weymouth and Portland was significant with an odds ratio of $6.550(\beta=1.879, p=.006)$. This appeared to confirm that those people who reported volunteering for the 2012 Olympics showed a greater intention to volunteer for future events (Lockstone-Binney et al., 2016). The result was consistent with the 2013 findings and has important implications in developing volunteering legacies.

\section{Discussions and conclusion}

Given the impact of mega-events on volunteering is rarely evaluated over an extended time period (Dickson et al., 2011), this study contributes to the literature by empirically testing host resident perceptions of mega-event legacies and the influence these may have on their 
future volunteering intentions, offering new insights as to how the delivery of Olympic volunteering legacies have changed over time. In doing so it also confirms some of the reservations of event scholars on the (in)effectiveness of host nations and communities to increase volunteer participation as a social legacy of the Games (Benson et al., 2014; Dickson et al., 2011; Nichols \& Ralston, 2014; Nichols \& Ralston, 2015; Lockstone-Binney et al., 2018). Findings from the present research provide an understanding of how residents' involvement in the 2012 Olympic Games affects intention to volunteer in the post-Games era.

Our findings reveal that resident's volunteering intention for future events declined from 2013 to 2016 . This may be explained by residents' interactions with the event and its impacts over time (Karadakis \& Kaplanidou, 2012). While residents' involvement in water sports and location of residence influence the initial volunteering for the 2012 Olympic Games, their actual volunteering experience, perceived event legacies, and commitment to the community demonstrate to be important factors that affect future volunteering. The results indicate that people's motivation and interest in volunteering evolve as they become more familiar and involved with the event, and participation in volunteering is more widespread and has a broader appeal than those solely with sailing interests. Interestingly, involvement in water sports shows a negative association with residents' actual volunteering and does not seem to influence their future volunteering. This not only suggests that water sport enthusiasts might be reluctant or skeptical towards volunteering for the Games, but also implies that the Games fail to create a sporting legacy through engagement with the local water sports communities.

The results further indicate that the Organising Committees for the Olympic Games (OCOGs) and host destinations should better engage with local residents to facilitate volunteering, not simply focusing on those who are interested in sport. Tentative evidence from Benson et al.'s (2014) study of the volunteer training legacy of Vancouver 2010 
Olympic and Paralympic Games suggests that a more proactive relationship between the OCOG and community groups may have led to a greater legacy for host city volunteering. Focusing on those involved in the Games' volunteer programme helps to cultivate future volunteering intentions, but this is insufficient to capture more ambitious legacy goals regarding enhanced volunteer participation and broader social inclusion agendas across society more generally (Benson et al., 2014; Dickson et al., 2011; Lockstone-Binney et al., 2016; Shipway et al., 2019). Findings from our research highlight that residents' volunteering intentions also hinge on their perceptions of how the event performs over time, suggesting a better management and communication of event legacies with key stakeholders (Bell \& Gallimore, 2015). It is recommended that both host cities and the IOC ensure there are dedicated, ring-fenced budgets for legacy planning efforts, and that this funding is ongoing to support longer-term legacy projects. Without such interventions, the much-lauded claims for developing existing and capturing new, volunteers as a legacy of mega-events like the Olympic Games are unlikely to be achieved.

Certain resident groups appear to be more likely to get involved in volunteering (whether actual or future), such as those who live within close proximity to the venue (i.e., residing within 4 miles from the venues), who are relatively new to the community (i.e., living in the area for between 1-3 years), and who are middle-aged (i.e., aged between 36 and $55)$, possibly because volunteering provides them with an avenue to engage with others in community and socialise (Dickson et al., 2014; Dickson et al., 2015). However, these factors cease to influence resident volunteering in 2016. Could it be that the glamour associated with the 2012 Olympic Games has dissipated? As such, mechanisms for guiding and mobilising these residents even in years after the event should be a priority for future event organisers. Interestingly, the 2013 data reveal that residents employed in the tourism sector are less inclined to volunteer for future events. Future research is needed to further understand 
motiviations underlying residents' (in)volunteering behaviours and how these may change over time.

In response to the identified declines in volunteering intentions from 2013 to 2016, future event host cities are encouraged to ensure that legacy plans, involving both Gamestime volunteers and those residents potentially 'inspired by the Games' to volunteer (LOCOG, 2013), are both promptly and effectively captured in the immediate post Games period. As highlighted in previous 'legacy' studies in Weymouth and Portland, those initiatives, especially the softer, intangible programmes, were frequently under resourced (Shipway et al., 2010), often leading to both the disengagement and disempowerment of host communities (Shipway et al., 2019). There has been criticism that the mechanisms and infrastructure needed to facilitate positive outcomes were actioned too late (Nichols \& Ralston, 2015). In addition to this, the previously identified lack of dedicated budgets for 2012 legacy efforts and the difficulties of sourcing funding, particularly recurrent post-event funding (Lockstone-Binney et al., 2016; Lockstone-Binney et al., 2018), although not explicitly tested, is highly probable to have played an influential role in the decreased intentions to volunteer highlighted in this study. In the final IOC Coordination Commission report of the London 2012 XXX Olympiad, it was recommended for 'OCOGs and their partners to allocate and protect a dedicated budget to support engagement programmes' (IOC, 2013, p. 42). The resulting decline in both current and future volunteering intentions, highlighted in this study, would appear to provide evidence that this was a significant missed opportunity.

Despite initiatives aimed at increasing volunteer participation featuring prominently in the bid books of prospective host cities (Holmes \& Smith, 2009), the frequent oversubscription for Games time volunteers (Lockstone \& Baum, 2009) and post-event volunteers being publicly encouraged to continue their volunteering efforts locally as a social legacy of 
the Games (IOC, 2012), the results from this study indicate that legacy plans and initiatives for the 2012 Games have not sufficiently engaged residents, especially in the post event period. As such, the results bring into question how far an Olympic volunteer programme can lead to a sustained positive legacy of longer-term volunteer participation in host destinations. The results also sit uncomfortably with one of the underlying objectives of the IOC, in terms of their stated aim of enabling residents of host nations to contribute to the success of the Olympic Games and a sustainable positive legacy (IOC, 2013). Additionally, it could also be argued that the findings conflict with the official post-event reports (LOCOG, 2013), where the volunteer programme was celebrated as a key success of the Games, and it was claimed that volunteering continued to be a prominent feature in discussions of legacy. Whilst Games-time volunteering was an overwhelming success, the success of post-Games initiatives and their ability to deliver tangible legacy outcomes remain a topic of debate (Lockstone-Binney et al., 2016).

Additionally, the findings of this study are transferable to non-Olympic Games major sport events, in both multi-sport and single-sport versions. Future research is required to explore resident perceptions of legacies and volunteering intentions commencing at the candidature/bidding stages of major sport events. In addition, future research is required with regards to how volunteering intentions might vary depending on both the type of sport event and the cultural traditions of the bid/host nations, whilst subsequently monitoring changes over the course of the sport event lifecycle, from the bidding to legacy realisation stages (IOC, 2018; Shipway et al., 2019).

Future research is required to better understand how volunteering intentions can be developed throughout host communities and further facilitate movement towards a volunteer culture to ensure a continued volunteering legacy surrounding the hosting of future megaevents. Kristiansen, Skirstad, Parent and Waddington (2015) established that community 
characteristics, such as the degree to which the community has a volunteering tradition, can influence volunteering intentions/behaviour. Future studies within a mega sport event context should explore the extent to which longer term volunteering might be understood in terms of levels of social integration, the creation of collective identities focused around mega-events whilst also maintaining and reinforcing strong community identities.

It was the foundational work on serious leisure by Stebbins (1982) that first highlighted the key role of volunteers in sustaining communities, whilst his more recent critique of social worlds and leisure experiences also identified the importance of understanding why people, including volunteers, are attracted to and continue with serious pursuits through their leisure involvement (Stebbins, 2018). Similarly, Fairley, Green, O'Brien and Chalip (2015) identified the importance of the social connections that volunteers create amongst themselves during sport events. They highlighted the roles of socialising and developing social connections in both making leisure experiences enjoyable and for supporting stronger commitment to the activity. Those research findings and the results of this study, which identified that resident's volunteering intention for future events declined from 2013 to 2016, appear to provide further evidence that in the transition period following the London 2012 Games insufficient tactics and strategies were utilised to better leverage opportunities arising from an enhanced sense of community amongst residents with both current and future volunteering intentions. This was most likely a further missed opportunity to better optimise volunteering involvement, as an integral part of enhancing post-event leisure experiences.

It is acknowledged that this study only provides a regional snapshot of resident perceptions towards volunteering intentions within a host destination, and as such there may be variations from the volunteering intentions within host boroughs and communities within the Olympic host city. In recognition of this limitation, and given the importance of the 
community in relation to sport event volunteering, future research should also explore the full spectrum of host communities and how they view the event legacies as well as the volunteering programmes at mega-events, and whether a volunteering legacy actually exists, beyond the glamour and outside of the formally official volunteer programmes and initiatives.

\section{References}

Auld, C., Cuskelly, G., \& Harrington, M. (2009). Managing volunteers to enhance the legacy potential of major events. Oxfordshire: CABI.

Bell, B. \& Gallimore, K. (2015). Embracing the games? Leverage and legacy of London 2012 Olympics at the sub-regional level by means of strategic partnerships. Leisure Studies, 34(6), 720-741.

Benson, A. M., Dickson, T. J., Terwiel, F. A., \& Blackman, D. A. (2014). Training of Vancouver 2010 volunteers: A legacy opportunity? Contemporary Social Science, $9(2), 210-226$.

Cegielski, M., \& Mules, T. (2002). Aspects of residents' perceptions of the GMC 400Canberra's V8 supercar race. Current Issues in Tourism, 5(1), 54-70.

Chien, P. M., Kelly, S. J., \& Gill, C. (2018). Identifying objectives for mega-event leveraging: a non-host city case. Marketing Intelligence \& Planning, 36(2), 168-184.

Chien, P. M., Ritchie, B. W., Shipway, R., \& Henderson, H. (2012). I am having a dilemma: factors affecting resident support of event development in the community. Journal of Travel Research, 51(4), 451-463.

Davies, L. E. (2012). Beyond the Games: regeneration legacies and London 2012. Leisure Studies, 31(3), 309-337.

DCMS. (2016). Inspired by 2012: the legacy from the Olympic and Paralympic Games 
Fourth Annual Report - Summer 2016. London: Department for Culture, Media and Sport (DCMS).

Dickson, T. J., Benson, A. M., \& Blackman, D. A. (2011). Developing a framework for evaluating Olympic and Paralympic legacies. Journal of Sport and Tourism, 16(4), 285-302.

Dickson, T. J., Benson, A. M., Blackman, D. A., \& Terwiel, F. A. (2013). It's all about the Games! 2010 Vancouver Olympic and Paralympic winter games volunteers. Event Management, 17(1), 77-92.

Dickson, T. J., Benson, A. M., \& Terwiel, F. A. (2014). Mega-event volunteers, similar or different? Vancouver 2010 vs London 2012. International Journal of Event and Festival Management, 5(2), 164-179.

Dickson, T. J., Darcy, S., Edwards, D., \& Terwiel, F. A. (2015). Sport mega-event volunteers' motivations and postevent intention to volunteer: The Sydney World Masters Games, 2009. Event Management, 19(2), 227-245.

Doherty, A. (2009). The volunteer legacy of a major sport event. Journal of Policy Research in Tourism, Leisure and Events, 1(3), 185-207.

Duignan, M. B., Pappalepore, I., \& Everett, S. (2019). The 'summer of discontent': Exclusion and communal resistance at the London 2012 Olympics. Tourism Management, 70, $355-367$.

Elstad, B. (2003). Continuance commitment and reasons to quit: a study of volunteers at a jazz festival, Event Management, 8(2), 99-108.

Fairley, S., Cardillo, M. L., \& Filo, K. (2016a). Engaging volunteers from regional communities: Non-host city resident perceptions towards a mega-event and the opportunity to volunteer. Event Management, 20(3), 433-447.

Fairley, S., Gardiner, S., \& Filo, K. (2016b). The spirit lives on: the legacy of volunteering 
at the Sydney 2000 Olympic Games. Event Management, 20(2), 201-215

Fairley, S., Kellett, P., \& Green, B. C. (2007). Volunteering abroad: Motives for travel to volunteer at the Athens Olympic Games. Journal of Sport Management, 21(1), 41-57.

Fairley, S., Green, B.C., O’Brien, D., \& Chalip, L. (2015). Pioneer volunteers: The role identity of continuous volunteers at sport events. Journal of Sport \& Tourism, 19, $233-255$.

Fredline, E., \& Faulkner, B. (2002). Residents' reactions to the staging of major motorsport events within their communities: a cluster analysis, Event Management, 7(2), 103-14.

Fredline, L., Raybould, M., Jago, L., \& Deery, M. (2005, July). Triple bottom line event evaluation: A proposed framework for holistic event evaluation. In J. Allen (Ed.), Proceedings of International Event Research Conference July.

Gibson, H.J., Walker, M., Thapa, B., Kaplanidou, K., Geldenhuys, S., \& Coetzee, W. (2014). Psychic income and social capital among host nation residents: A pre-post analysis of the 2010 FIFA World Cup in South Africa. Tourism Management, 44, 113-122.

Gold, J. R., \& Gold, M. M. (2008). Olympic cities: regeneration, city rebranding and changing urban agendas. Geography Compass, 2(1), 300-318.

Gursoy, D., \& Kendall, K. W. (2006). Hosting mega events: Modeling locals' support. Annals of Tourism Research, 33(3), 603-623.

Gursoy, D., Yolal, M., Ribeiro, M. A., \& Panosso Netto, A. (2017). Impact of trust on local residents' mega-event perceptions and their support. Journal of Travel Research, 56(3), 393-406.

Hallmann, K., \& Harms, G. (2012). Determinants of volunteer motivation and their impact on future voluntary engagement: A comparison of volunteer's motivation at sport events in equestrian and handball. International Journal of Event and Festival Management, 3(3), 272-291. 
Hiller, H. H., \& Wanner, R. A. (2011). Public opinion in host Olympic cities: The case of the 2010 Vancouver Winter Games. Sociology, 45(5), 883-899.

Holmes, K., \& Smith, K. A. (2009). Managing volunteers in tourism: Attractions, destinations and events. Oxford: Butterworth-Heinemann.

Holmes, K., Hughes, M., Mair, J., \& Carlsen, J. (2015). Events and Sustainability. Abingdon: Routledge.

International Olympic Committee (IOC) (2012). Olympic legacy. Lausanne: International Olympic Committee (IOC).

International Olympic Committee (IOC) (2013). Final report of the IOC Coordination Commission: Games of the XXX Olympiad, London 2012. Lausanne: International Olympic Committee (IOC).

International Olympic Committee. (2014). Olympic Agenda 2020. Lausanne: International Olympic Committee (IOC).

International Olympic Committee (IOC) (2018). Olympic Agenda 2020. Olympic Games: the New Norm. Lausanne: International Olympic Committee (IOC).

Kaplanidou, K., Karadakis, K., Gibson, H., Thapa, B., Walker, M., Geldenhuys, S., \& Coetzee, W. (2013). Quality of life, event impacts, and mega-event support among South African residents before and after the 2010 FIFA World Cup. Journal of Travel Research, 52(5), 631-645.

Karadakis, K., \& Kaplanidou, K. (2012). Legacy perceptions among host and non-host Olympic Games residents: A longitudinal study of the 2010 Vancouver Olympic Games. European Sport Management Quarterly, 12(3), 243-264.

Kim, H. J., Gursoy, D., \& Lee, S. B. (2006). The impact of the 2002 World Cup on South Korea: Comparisons of pre- and post-games, Tourism Management, 27(1), 86-96. Kim, S. S., \& Petrick, J. F. (2005). Residents' perceptions on impacts of the FIFA 2002 
World Cup: the case of Seoul as a host city. Tourism Management, 26(1), 25-38.

Kristiansen, E., Skirstad, B., Parent, M. M., \& Waddington, I. (2015). 'We can do it':

Community, resistance, social solidarity, and long-term volunteering at a sport event. Sport Management Review, 18(2), 256-267.

Lee, S. B., Lee, C. K., Kang, J. S., Lee, E. Y., \& Jeon, Y. J. (2012). Residents' perception of the 2008 Beijing Olynpics: Comparison of pre- and post-impacts. International Journal of Tourism Research, 15(3), 209-225.

Leopkey, B., \& Parent, M. M. (2012). Olympic Games legacy: From general benefits to sustainable long-term legacy. International Journal of the History of Sport, 29(6), 924-943.

Leopkey, B., \& Parent, M. M. (2017). The governance of Olympic legacy: Process, actors and mechanisms. Leisure Studies, 36(3), 438-451.

Lockstone, L., \& Baum, T. (2009). The public face of event volunteering at the 2006 Commonwealth Games: The media perspective. Managing Leisure, 14(1), 38-56.

Lockstone-Binney, L., Holmes, K., Shipway, R., \& Smith, K. (2016). Evaluating the volunteering infrastructure legacy of the Olympic Games: Sydney 2000 and London 2012. International Olympic Committee Olympic Studies Centre, Lausanne, Switzerland.

Lockstone-Binney, L., Holmes, K., Smith, K. A., \& Shipway, R. (2018). The role of corporates in creating sustainable Olympic legacies. Journal of Sustainable Tourism, 26(11), 1827-1844.

LOCOG. (2013). London 2012 Olympic Games official report, volume 3. London: London Organising Committee of the Olympic and Paralympic Games (LOCOG).

Love, A., Hardin, R., Koo, W., \& Morse, A. L. (2011). Effects of motives on satisfaction and behavioral intentions of volunteers at a PGA tour event. International Journal of 
Sport Management, 12(1), 86-101.

Liu, D., Broom, D., \& Wilson, R. (2014). Legacy of the Beijing Olympic Games: a nonhost city perspective. European Sport Management Quarterly, 14(5), 485-502.

Minnaert, L. (2012). An Olympic legacy for all? The non-infrastructural outcomes of the Olympic Games for socially excluded groups (Atlanta 1996-Beijing 2008). Tourism Management, 33(2), 361-370.

Nichols, G. (2013) Volunteering for the Games. In V. Girginov (ed.) The London 2012 Olympic and Paralympic Games. Volume one: Making the Games. London: Routledge, 215-224.

Nichols, G., \& Ralston, R. (2012). Lessons from the volunteering legacy of the 2002 Commonwealth Games. Urban Studies, 49(1), 169-184.

Nichols, G., \& Ralston, R. (2014) The 2012 Ambassadors:- -second class Olympic volunteers or the best potential for developing a volunteering legacy from the Games? In K. Smith, L. Lockstone, K. Holmes and T. Baum (Eds.) Event Volunteering, International Perspectives on the Event Volunteering Experience. Abingdon: Routledge. 167-181.

Nichols, G., \& Ralston, R. (2015) The legacy costs of delivering the 2012 Olympic and Paralympic Games through regulatory capitalism. Leisure Studies, 34(4) 389-404.

Nichols, G., Ralston, R., \& Holmes, K. (2017) The 2012 Olympic Ambassadors and sustainable tourism legacy. Journal of Sustainable Tourism, 25(11), 1513-1528.

Nomis (2017) Available from:

https://www.nomisweb.co.uk/reports/lmp/la/1946157371/report.aspx Accessed 10 May 2018.

Office for National Statistics (2017). Retrieved from https://www.ons.gov.uk/peoplepopulationandcommunity 
Pappalepore I., \& Duignan, M. (2016). The London 2012 cultural programme: A consideration of Olympic impacts and legacies for small creative organsiations in east London. Tourism Management, 54, 344-355.

Prayag, G., Hosany, S., Nunkoo, R., \& Alders, T. (2013). London residents' support for the 2012 Olympic Games: The mediating effect of overall attitude. Tourism Management, $36,629-640$.

Preuss, H. (2007). The conceptualisation and measurement of mega sport event legacies. Journal of Sport \& Tourism, 12(3-4), 207-228.

Ritchie, J. B. (2000). Turning 16 days into 16 years through Olympic legacies. Event Management, 6(3), 155-165.

Ritchie, B. W., \& Inkari, M. (2006). Host community attitudes towards tourism and cultural tourism development: the case of the Lewes District, Southern England. International Journal of Tourism Research, 8, 27-44.

Ritchie, B. W. Shipway, R., \& Cleeve, B. (2009). Resident perceptions towards megasporting events: A non-host city perspective of the 2012 London Olympic Games. Journal of Sport and Tourism, 14(2-3), 143-167.

Ritchie, B. W., Shipway, R., \& Chien, P. M. (2010). The role of the media in influencing resident support for the 2012 Olympic Games. International Journal of Event and Festival Management, 1(3), 202-219.

Rocha, C. M. Barbanti, V. J. and Chelladurai, P (2017) Support of local residents for the 2016 Olympic Games. Event Management, 21, 251-268.

Shipway, R. (2007). Sustainable Legacies for the 2012 Olympic Games. The Journal of the Royal Society for the Promotion of Health, 127(30), 119-124.

Shipway, R., Henderson, H., \& Stuchberry, L. (2010). Weymouth and Portland 2012 
Residents Opinion Research. Unpublished Report. Weymouth and Portland Borough Council. Weymouth.

Shipway, R., Lockstone-Binney, L., Holmes, K., \& Smith, K., (2019). Perspectives on the Volunteering Legacy of the London 2012 Olympic Games: The Development of an Event Legacy Stakeholder Engagement Matrix. Event Management.

Smith, A. (2014). Leveraging sport mega-events: New model of convenient justification? Journal of Policy Research in Tourism, Leisure \& Events, 6(4), 15-30.

Smith, A., Ritchie, B. W., \& Chien, P. M. (2019). Citizens' attitudes towards mega-events: A new framework. Annals of Tourism Research, 74, 208-210.

Stebbins, R.A. (1982). Serious leisure: A conceptual statement. Pacific Sociological Review, $25,251-72$.

Stebbins, R.A. (2018). Social worlds and the leisure experiences. Bingley: Emerald Publishing Limited.

South West Regional Development Agency (SWRDA) (2007) South West England Legacy Strategy for the 2012 Games. Exeter: SWRDA.

Wicker, P. (2017) Volunteerism and volunteer management in sport. Sport Management Review, 20, 325-337.

Zhou, Y., \& Ap, J. (2009). Residents' perceptions towards the impacts of the Beijing 2008 Olympic Games. Journal of Travel Research, 48(1), 78-91. 
Table 1. Questionnaire breakdown and response rate

\begin{tabular}{|l|l|l|l|}
\hline $\begin{array}{l}\text { Survey } \\
\text { year }\end{array}$ & $\begin{array}{l}\text { Number of } \\
\text { questionnaires } \\
\text { distributed }\end{array}$ & $\begin{array}{l}\text { Number of usable } \\
\text { returned } \\
\text { questionnaires }\end{array}$ & $\begin{array}{l}\text { Questionnaire } \\
\text { Response rate } \\
\%\end{array}$ \\
\hline 2013 & 5000 & 929 & $18.60 \%$ \\
\hline 2016 & 3750 & 565 & $15.10 \%$ \\
\hline
\end{tabular}


Table 2. 2013 Variables Associated with Future Volunteering Intentions (2013 sample)

\begin{tabular}{|c|c|c|c|c|c|c|c|c|}
\hline \multirow[b]{2}{*}{ Variables } & \multirow[b]{2}{*}{ B } & \multirow[b]{2}{*}{ S.E. } & \multirow[b]{2}{*}{ Wald } & \multirow[b]{2}{*}{ df } & \multirow[b]{2}{*}{ Sig. } & \multirow[b]{2}{*}{$\operatorname{Exp}(B)$} & \multicolumn{2}{|c|}{$\begin{array}{l}\text { 95\% C.I.for } \\
\text { EXP(B) }\end{array}$} \\
\hline & & & & & & & Lower & Upper \\
\hline Commitment & 0.027 & 0.015 & 3.560 & 1 & $0.059 *$ & 1.028 & 0.999 & 1.058 \\
\hline $\begin{array}{l}\text { Perceived } \\
\text { Legacies }\end{array}$ & 0.727 & 0.188 & 14.912 & 1 & $0.000 * *$ & 2.070 & 1.431 & 2.994 \\
\hline $\begin{array}{l}2012 \\
\text { Volunteering }\end{array}$ & 2.514 & 0.556 & 20.480 & 1 & $0.000 * *$ & 12.356 & 4.159 & 36.710 \\
\hline $\begin{array}{l}\text { Event } \\
\text { attendance }\end{array}$ & 0.324 & 0.067 & 23.259 & 1 & $0.000 * *$ & 1.383 & 1.212 & 1.578 \\
\hline $\begin{array}{l}\text { Tourism } \\
\text { Involvement }\end{array}$ & 0.135 & 0.433 & 0.097 & 1 & 0.756 & 0.874 & 0.374 & 2.042 \\
\hline $\begin{array}{l}\text { Water sport } \\
\text { Involvement }\end{array}$ & 0.191 & 0.276 & 0.476 & 1 & 0.490 & 1.210 & 0.704 & 2.079 \\
\hline Gender & 0.297 & 0.233 & 1.628 & 1 & 0.202 & 1.346 & 0.853 & 2.124 \\
\hline $\begin{array}{l}\text { Length of } \\
\text { residence } \\
\text { (<1 year) }\end{array}$ & 0.213 & 1.155 & 0.034 & 1 & 0.853 & 0.808 & 0.084 & 7.773 \\
\hline $1-3$ years & 1.504 & 0.439 & 11.715 & 1 & $0.001 *$ & 4.501 & 1.902 & 10.651 \\
\hline 4-6 years & 0.212 & 0.495 & 0.183 & 1 & 0.669 & 1.236 & 0.468 & 3.259 \\
\hline $7-10$ years & 0.102 & 0.423 & 0.058 & 1 & 0.810 & 0.903 & 0.395 & 2.068 \\
\hline $\begin{array}{l}\text { Location } \\
(<0.5 \text { mile })\end{array}$ & 3.521 & 2.349 & 2.247 & 1 & 0.134 & 0.030 & 0.000 & 2.954 \\
\hline $\begin{array}{l}\text { Less than a } \\
\text { mile }\end{array}$ & 1.847 & 1.684 & 1.203 & 1 & 0.273 & 0.158 & 0.006 & 4.275 \\
\hline $1-2$ miles & 2.116 & 1.609 & 1.729 & 1 & 0.189 & 0.120 & 0.005 & 2.823 \\
\hline 3-4 miles & 2.132 & 1.598 & 1.780 & 1 & 0.182 & 0.119 & 0.005 & 2.719 \\
\hline $4+$ miles & 2.026 & 1.595 & 1.612 & 1 & 0.204 & 0.132 & 0.006 & 3.007 \\
\hline $\begin{array}{l}\text { Age } \\
(16-25 \\
\text { years })\end{array}$ & 1.035 & 0.816 & 1.608 & 1 & 0.205 & 2.816 & 0.569 & 13.948 \\
\hline $26-35$ & 1.285 & 0.498 & 6.657 & 1 & $0.010 *$ & 3.615 & 1.362 & 9.595 \\
\hline $36-45$ & 1.406 & 0.373 & 14.170 & 1 & $0.000 * *$ & 4.079 & 1.962 & 8.480 \\
\hline $46-55$ & 1.210 & 0.329 & 13.490 & 1 & $0.000 * *$ & 3.354 & 1.758 & 6.397 \\
\hline $55-64$ & 0.883 & 0.312 & 7.991 & 1 & $0.005 *$ & 2.418 & 1.311 & 4.461 \\
\hline
\end{tabular}

${ }^{*} \mathrm{p}<0.05,{ }^{* *} \mathrm{p}<0.001$ 